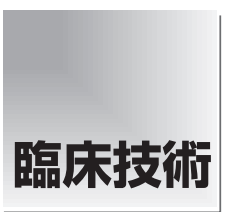

論文受付 2009年10月13日 論文受理 2011 年 4 月30日 Code No. 190

\section{救命救急室ポータブル撮影業務での 手指衛生行動について}

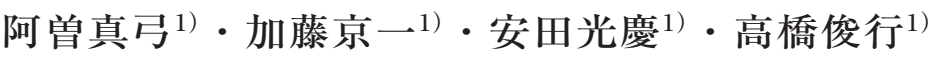 \\ 崔 昌五 ${ }^{2)} \cdot$ 藤村一正 ${ }^{3)} \cdot$ 黑木一典 ${ }^{4)} \cdot$ 中澤靖夫 ${ }^{5)}$
}

\section{緒 言}

全国的にメチシリン耐性黄色ブドウ球菌 (methicillinresistant Staphylococcus aureus; MRSA)や多剂耐性緑 膿菌 (multidrug-resistant pseudomonas aeruginosa; MDRP)など薬剂耐性菌の病院内感染が問題になって いる。診療放射線技師(以下技師) は撮影業務に抒い てポータブル撮影等でMRSA 陽性患者に接する機会 が多い。その際に撮影を担当した技師の手指やイ メージングプレート (imaging plate; IP) カセッテから菌 が伝播される可能性は高く, 実際に技師が病院内感
染の伝播原因となった報告もある11).感染症患者や易 感染症患者に接する機会の多い技師も感染対策方 法，手洗いまたは速乾性手指消毒薬を使用すると いった手指衛生の方法や個人防護具の使用タイミン グなどを身に付ける必要がある。病院内感染や菌の 伝播に関する報告は他職種ではあるが2,3)技師の報告 はない.

そこで, 当院の救命救急撮影準備室の污染状況を 調查し, 改善方法を検討した。

\title{
Hand Hygiene during Mobile X-ray Imaging in the Emergency Room
}

\author{
Mayumi Aso,") Kyoichi Kato,") Mitsuyoshi Yasuda,") Toshiyuki Takahashi,," Syogo Say, ${ }^{2)}$ \\ Kazumasa Fujimura, ${ }^{3)}$ Kazunori Kuroki, ${ }^{4)}$ and Yasuo Nakazawa ${ }^{5)}$ \\ 1 ) Department of Radiology, Showa University Fujigaoka Hospital \\ 2) Department of Radiology, Showa University Hospital \\ 3) Department of Radiology, Showa University Northern Yokohama Hospital \\ 4) Department of Radiology, Showa University Fujigaoka Hospital \\ 5) Department of Radiology, Showa University \\ Received October 13,2009; Revision accepted April 30, 2011; Code No. 190
}

\section{Summary}

A hand hygiene behavior questionnaire and environmental survey were conducted regarding the mobile $\mathrm{X}$-ray system used in the emergency room. As a result, among a total of 22 radiological technologists at this hospital who replied to the questionnaire, 18 wore disposable gloves when performing X-ray imaging using the mobile system. Among those 18, 11 were found to touch computed radiology (CR) consoles and HIS/RIS terminals while still wearing the gloves, thus creating the potential for spreading pathogens to other medical equipment and systems. According to the results of an environmental survey of the emergency imaging preparation room, the highest levels of bacteria were detected on CR consoles and HIS/RIS terminals. A possible reason for this is that these locations are not wiped down and cleaned as a part of routine cleaning and disinfection protocols, thus demonstrating the importance of cleaning and disinfection. Hand hygiene by medical personnel and appropriate cleaning and disinfecting of the working environment are important for preventing the spread of nosocomial infections. Radiological technologists are also required to take effective measures against infections in consideration of the high frequency of contact with both infected patients and patients susceptible to infections.

Key words: hand hygiene, infection control, hand wash, mobile X-ray system, environmental sampling

別刷資料請求先： $=227-8501$ 神奈川県横浜市青葉区藤が丘 1-30 


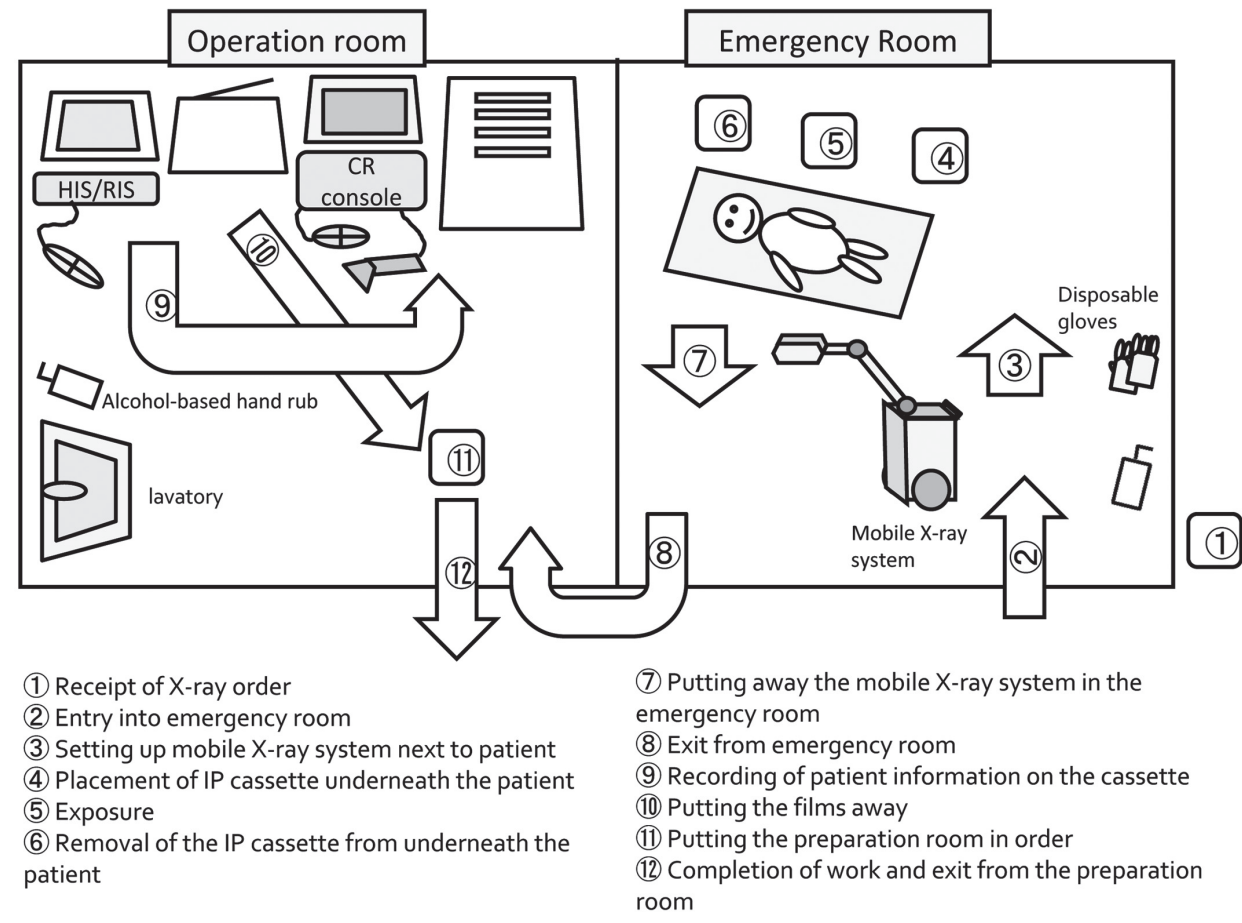

Fig. 1 Imaging procedure during use of the mobile X-ray system in the emergency room.

\section{1. 方 法}

\section{1-1 使用機器}

環境調查対象装置として, hospital information system/ radiology information system 用パソコン端末(以下 HIS/ RIS 端末, NEC 社製)，画像処理ユニット computed radiography コンソール(以下 CR コンソール, 富士フ イルムメディカル社製)，IP カセッテ(富士フイルムメ デイカル社製), 回診用 X 線撮影装置 MOBILETT Plus(SIEMENS 社製)を用いた。接触交差伝播実験使 用物品として，手洗いトレーニングボックス：Glitter $\operatorname{Bug}$ (Brevis 社製)，蛍光色素含有塗料：専用蛍光パ ウダ(Brevis 社製)，画像処理ソフト:Adobe Photoshop Ver.5.5(Adobe Systems 社製)，また環境調査使用物 品として生理食塩水, 滅菌綿棒, 血液寒天培地, ド リガルスキー培地, No.110 番培地を用いた.

\section{1-2 救命救急室でのポータブル撮影業務における 手指衛生行動アンケート}

救命救急室でのポータブル (以下救急ポータブル) 撮影業務に打ける技師の手指衛生タイミングの実際 を確認するために，アンケートを行った，撮影要請を 受けてから業務完了までの間に，手指衛生を行う夕 イミングおよびディスポーザブル手袋(以下手袋)を着 用している時期について調査した。

手洗いタイミングアンケートは, Fig. 1 に示す撮影 要請から業務完了までの行動を 12 に区分けし，Fig. 2 に示すアンケート用紙に流水による手洗いまたは，ア
ルコール含有擦式手指消毒剂(以下アルコール)によ る手指衛生を行うタイミングの項目名を選択しても らった。同様に手袋を着用している時期の項目を選択

してもらった。

アンケート対象は, 当院放射線部所属の救急ポー タブル撮影業務を担当する技師 22 名(平均技師歴 $6.4 \pm 4.7$ 年)である. 回答率は $100 \%$ であった.

\section{1-3 接触交差伝播実験}

接触交差感染伝播がどの程度起こるかを目視で確 認できるように，蛍光色素含有塗料を用いて測定を 行った.

蛍光色素含有塗料を両手に均一に塗布し, その手 でプラスチック板の平面に約 3 秒接触を行い伝播 1 回目とした，次に別の被験者の手で前者が接触した 部位に約 3 秒接触し, 別の平面に接触を行った。こ れを伝播 2 回目とした。

それぞれの手形をブラックライトで蛍光させデジタ ルカメラで撮影し, 得られた手形画像の画像解析を 行った.

画像はサイズ 540×600 ピクセルとし, Adobe Photoshop を用い二極化処理を行い，ヒストグラムにて白のピク セル数(以下ピクセル数)を計測し比較を行った.

また，回診用 $\mathrm{X}$ 線撮影装置での伝播状態を把握す るため, 蛍光色素含有塗料を両手に均一塗布し，そ の手で通常の撮影業務と同様に回診用 $\mathrm{X}$ 線撮影装置 のハンドル部分に接触させ，その後別の被験者の手 
Questionnaire of hand hygiene at emergency

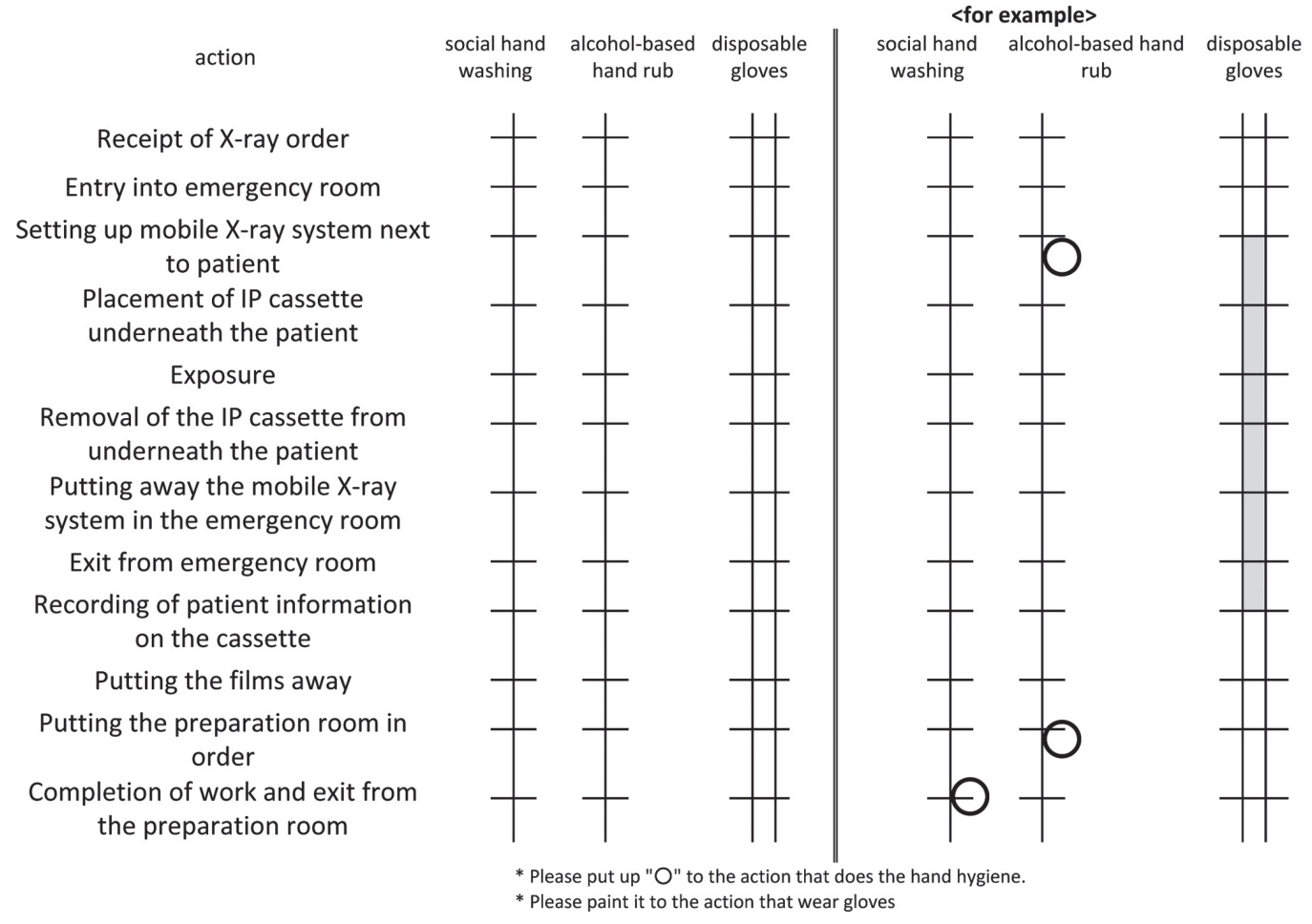

Fig. 2 Hand hygiene behavior questionnaire regarding use of the mobile X-ray system in the emergency room.

で同様にハンドルに接触させた，伝播前の両手，污 染されたハンドル部分, 伝播後の両手をブラックライ トで蛍光させデジタルカメラで撮影を行い, 目視にて 伝播状況を確認した.

\section{1-4 救命救急撮影準備室内機器の表面付着菌検査}

救急ポータブル撮影業務で, 準備室内での技師の 接触頻度の高い, 半切 IP カセッテの表面, 回診用 X 線撮影装置のハンドルと天板部分, 回診用 $\mathrm{X}$ 線撮影 装置の電源ケーブル，CR コンソール，HIS/RIS 端末 の 5 カ所に対し環境調査を行った。それらの機器の 日常感染対策管理状況は, IP カッテは撮影ごと に, 回診用 X 線撮影装置は仕業(始業, 終業) 点検時 にアルコール清拭されていた，CR コンソールや HIS/ RIS 端末などを清拭する日常業務は施行されていな かった。

前述した 5 カ所に対し生理食塩水で湿らせた滅菌 綿棒で拭い，表面付着菌を採取した。 日常状態での 調査を行うために担当技師に事前に連絡は行わず, 日勤業務終了直前に採取を行った.

IP カセッテは患者に接触する表面を 2 往復拭っ た。回診用 X 線撮影装置は, IP カセッテを置く天板 部分とハンドル部分を 2 往復, 電源ケーブルは, 本 体側から差し込みプラグまでを 2 往復拭った。 CR コ ンソールはタッチパネル表面とキーボードのキートッ
プ部，バーコードリーダーのグリップ部分を 2 往復, HIS/RIS 端末はキーボードのキートップ部とマウス表 面を 2 往復拭い採取を行った。採取した菌を各培地 に塗布し， $35^{\circ} \mathrm{C}$ にて 48 時間培養した。検出された菌 に対し同定を行った。

\section{2. 結 果}

2-1 救急ポータブル撮影業務における手指衛生 行動アンケート

救急ポータブル撮影業務では接触予防策を講じな くてはならず，患者や患者周辺の環境に触れる際手 袋を着用し，手袋を外した直後に手指衛生を行わな くてはならない，救急ポータブル撮影業務に打ける手 指衛生行動アンケートから手指衛生に対する行動が 明らかになった(Fig. 3)，得られた回答で代表的な手 指衛生に対する代表的な行動として，A は患者接触 前，手袋脱着時にアルコール使用と接触予防策対象 である救急患者接触時の手袋の着用が行われてい る、Bは，患者に接する直前に手袋を着用し，手袋を 外した後のアルコール使用はない，Cは，撮影業務 開始から終了まで手袋を着用している。Dは，手袋を 着用せず，撮影行動の最初と最後にアルコールを使 用している。 $\mathrm{E}$ は，手袋着脱前後にアルコールを使用 しており，手袋を外すタイミングは IP 登録やフィル ム整理が終了したあとであった。 


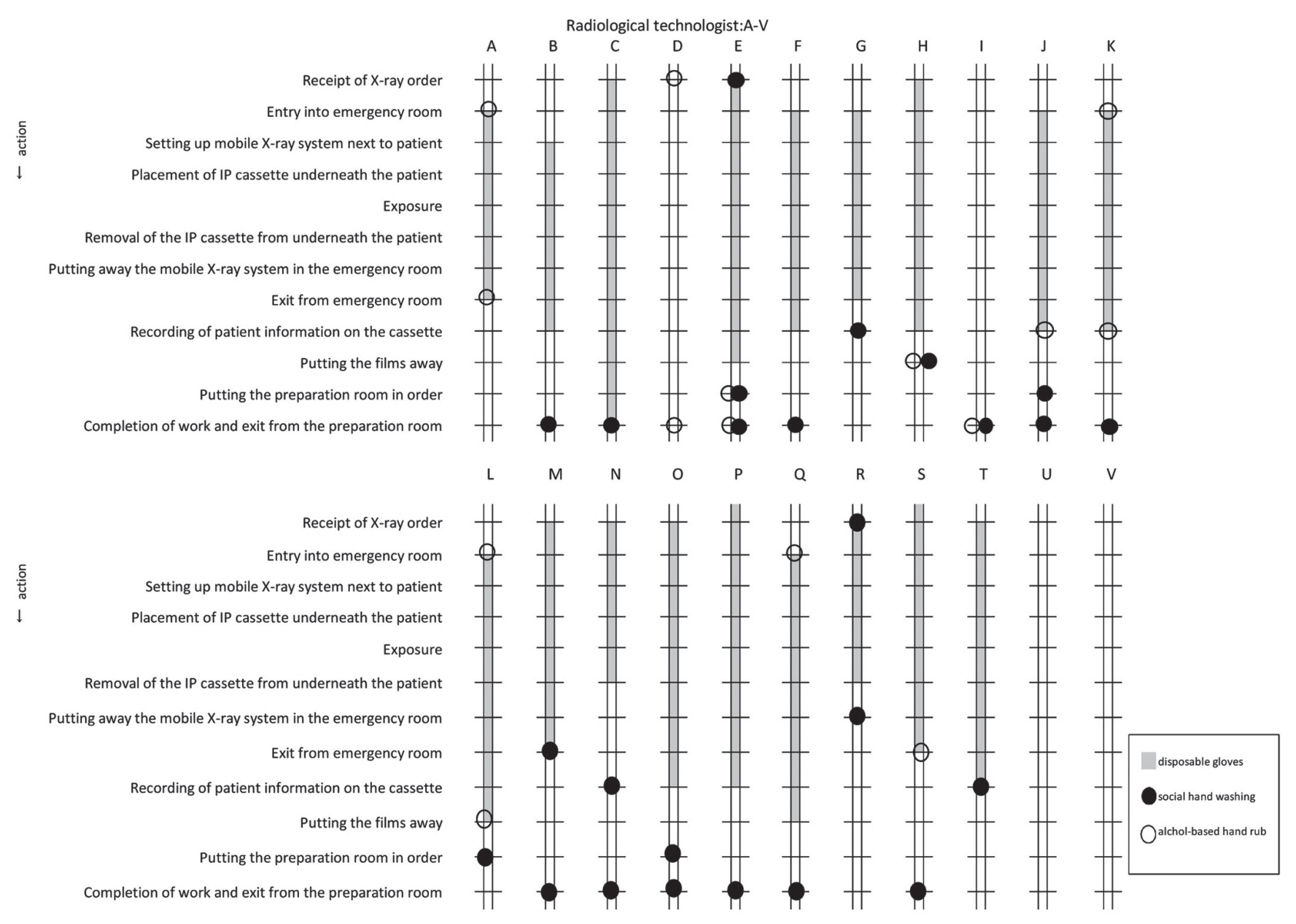

Fig. 3 Replies to the hand hygiene behavior questionnaire regarding use of the mobile X-ray system in the emergency room.

全体を通して手袋の着用行動に注目すると，曝射 時には 18 名が手袋を着用していた，曝射を終え IP カセッテを取り除いた時に手袋を 2 名が外し，救命 救急室を退室する前に 4 名が手袋を外した。そし て，12名が手袋を着用したままCRコンソールや HIS/RIS 端末に触れ，患者情報登録行為を行ってい た． 2 名が手袋を着用せず手指衛生のみを行い， 2 名 がなにも対策を講じていなかった。手袋着用と手洗 い行為をあわせて見てみると，手袋を脱いだ直後に 5 名がアルコールによる手指衛生を行い，1名が流水に よる手指衛生を行っていた。

\section{2-2 接触交差伝播実験}

手に付着した蛍光色素含有塗料と得られた手形の 写真のピクセル数を Table 1 に示す.

接触前の手のピクセル数は 106092 であった，伝播 1 回目のピクセル数は 53213 で, 伝播 2 回目でのピク セル数は 7862 であった。

伝播 1 回目で約 $15 \%$, 伝播 2 回目では接触交差伝 播実験開始時の約 7\%が伝播された。

また，回診用 $\mathrm{X}$ 線撮影装置ハンドル部を使用した
接触交差伝播実験でも, 別の被験者の手に蛍光色素 含有塗料の付着が確認できた(Fig. 4).

\section{2-3 救命救急撮影準備室内機器の表面付着菌検査}

環境調査にて調査を行った場所と同定された菌を Table 2 に，培養で得られた菌の写真を Fig. 5, 6 で 示す.

環境調査にて半切 IP カセッテで CNS (coagulase negative Staphylococci: コアグラーゼ陰性ブドウ球菌) 1+, GPC (gram-positive cocci: グラム陽性球菌)+, Bacillus sp.(Bacillus species: バチルス属)+, GPR (gram-positive rods: グラム陽性桿菌) $2+$ が検出, 回診用 X 線撮影装置ハンドル部 CNS 2+, GPR (1) 2+, GPC + , Bacillus sp. + が, 回診用 $\mathrm{X}$ 線撮影装置電源コード CNS +, GNFR (glucose-non fermentative gram-negative rods: ブドウ糖非発酵グラム陰性桿菌)+, Bacillus sp.+, GPR 2+, MSSA(methicillin-sensitive Staphylococcus aureus: メチシリン感受性黄色ブドウ球菌)+を, CR コンソールでCNS 2+, GPC 2+, GPR 2+, Bacillus sp. +, MSSA +, 糸状菌+を, HIS/RIS 端末で CNS 2+, GPC 1+, GPR 2+, Bacillus sp. + が検出された. 
Table 1 Results of contact and cross-infection experiment

\begin{tabular}{lcl}
\hline \hline & Pixels & \\
\hline Before & 106092 \\
The first & 53213 \\
& \\
The second & \\
& \\
\hline
\end{tabular}

Picture size 540×600 pixel, total 324000 pixels, threshold 128

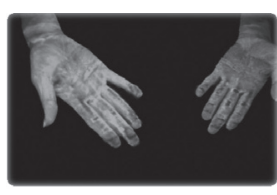

(1) Hands uniformly coated with fluorescent pigment-containing coating

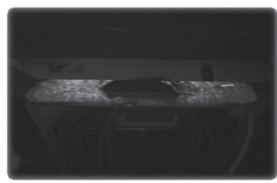

(2) Handle of mobile X-ray system touched by hands on which fluorescent pigment-containing coating was present

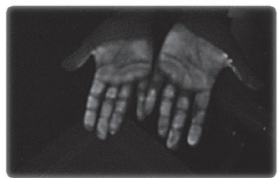

(3) Hands of different subject who touched handle of mobile X-ray system on which fluorescent pigment-containing coating was present

Fig. 4 Spread of fluorescent pigment-containing coating to hands and X-ray diagnostic equipment based on the results of contact and cross-infection experiment.

Table 2 Results of the environmental survey of emergency room imaging preparation room September 272006 enforcement

\begin{tabular}{cl}
\hline \hline An investigation point & \multicolumn{1}{c}{ Name of detected bacterium } \\
\hline IP cassette (17×14) & CNS 1+, GPC +, Bacillus sp. +, GPR 2+ \\
A handle of Mobile X-ray system & CNS 2+, GPR 2+, GPC +, Bacillus sp. + \\
Power supply cord of Mobile X-ray system & CNS +, GNFR +, Bacillus sp. +, GPR 2+, MSSA + \\
CR console & CNS 2+, GPC 2+, GPR 2+, Bacillus sp. +, MSSA +, A filamentous fungus + \\
A PC terminal for HIS/RIS & CNS 2+, GPC 1+, GPR 2+, Bacillus sp. +
\end{tabular}

CNS: coagulase negative Staphylococcus (excluding Staphylococcus aureus),

GPC: glam-positive cocci (excluding genus Staphylococcus, enterococcus streptococcaceae)

GPR: gram-positive rods,

A filamentous fungus: Fungi (Mold)

MSSA: methicillin-sensitive staphylococcus aureus

GNFR: a glucose non-fermentation gram negative bacterium

$<$ Reference value $>$

$+:$ a very small amount,

$1+:$ a small amount,

$2+:$ a medium amount

$3+$ : many

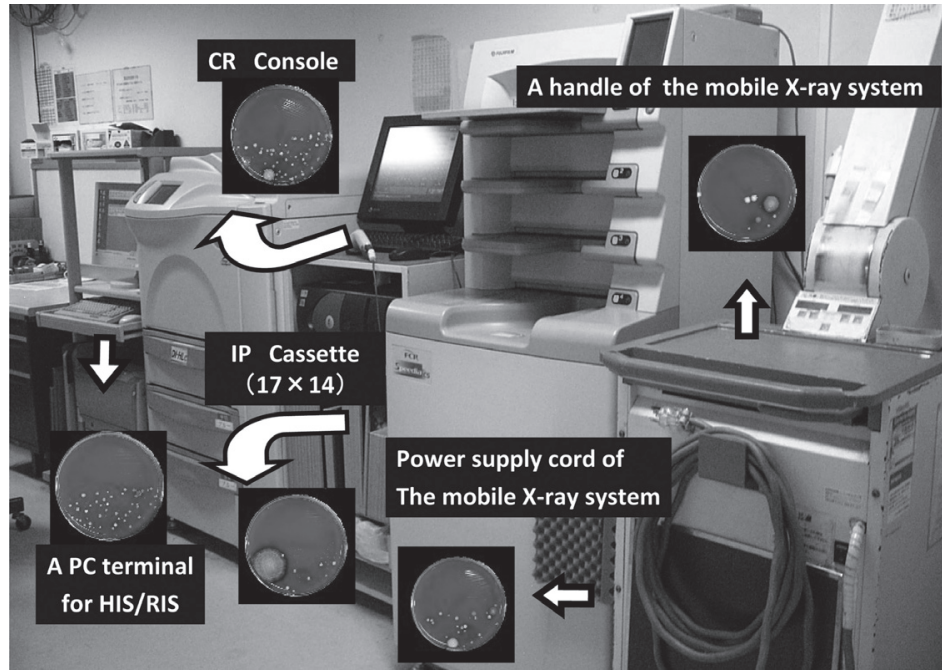

Fig. 5 Results of culturing bacteria obtained in the emergency room imaging preparation room and environmental survey. 


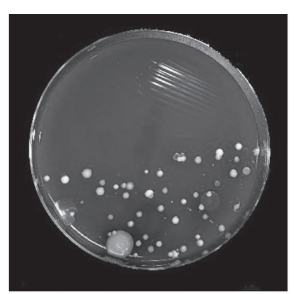

CR Console

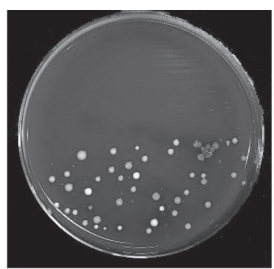

A PC terminal for HIS/RIS

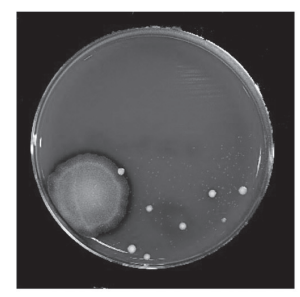

IP Cassette

$(17 \times 14)$

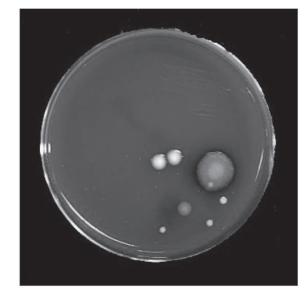

A handle of the mobile Power supply cord of the X-ray system

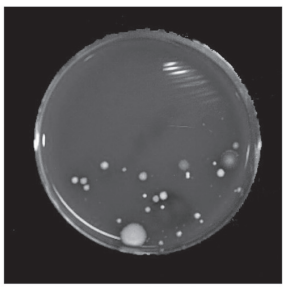

mobile X-ray system

Fig. 6 Results of culturing bacteria obtained in teh environmental survey.

検出された菌はいずれも常在菌であり，感染対策 上特に問題になる菌の検出はなかった。細菌検出量 を比較すると $2+$ と中等量の菌量のものが 9 検出され ており，特にCR コンソールと HIS/RIS 端末にて多く 検出された.

\section{3. 考 察}

救急ポータブル撮影時のアンケート結果から 81.8\%の技師が手袋を着用し $91.1 \%$ の技師が検查終 了するまでに手指衛生の実施がされていた，当院で は，RIS コメントに患者の感染症情報を記入している ため容易に感染症情報が得られる。また，月 1 回技 師対象に感染対策の勉強会を行っているため, 感染 対策の意識をしやすい環境であると考えられた，し かし，手指衛生タイミングのアンケート結果を見る と，接触予防策を講じるべき場面にも拘わらず手袋を 着用していない，手袋を外した後すぐに手指衛生を していないなど感染対策効果の得られない行動が見 られた。この要因として救命業務という特性上, 撮影 業務時間を優先することにより，感染対策を軽視する ことが考えられた。

米国疾病予防管理センター (centers for disease control and prevention; CDC)による医療現場に扔ける手指衛 生のためのガイドライン ${ }^{4)}$ および隔離予防策のガイド ライン ${ }^{5)}$ では，標準予防策において，手指衛生は微生 物伝播を減らす重要な要素であり, 患者と接触する 前，患者の皮膚や周辺の物品や環境に接触した時， 血液, 体液, 分泌物, 排泄物などと接触したあと, 手袋を外したあとの手指衛生を推奨している，個人 防護具として手袋を使用する場合, 着脱タイミングと 外した後の手指衛生を適切に行う必要があるが, 推
奨される予防策が実行されていない現状もあり，今 後感染予防策に対し更なる教育が必要であると考え られた。

接触交差伝播実験の結果より, 視覚的に蛍光色素 含有塗料の伝播の様子を確認できた，塗料の伝播を 菌の伝播とまったく同様に扱うことはできないが，手 に付着した菌の 2 次, 3 次伝播の可能性が考えられ た。放射線撮影検查を受ける患者は外来患者から病 棟まで幅が広いため, 医療用撮影機器がアウトブレ イクの感染源になった場合，影響を及ぼす範囲は非 常に大きいと考えられた。

救命救急撮影準備室での環境調査では, 直接患者 に触れる IP カセッテよりも, HIS/RIS 端末や CR コン ソールからの菌の検出量が多かった。これは, IP カ セッテは撮影ごとに, 回診用 X 線撮影装置は仕業 (始業, 終業) 点検ごとにアルコール清拭を行ってい るが，HIS/RIS 端末やCR コンソールでは，アルコー ル清拭を行っていないためと考えられた.

医療従事者の業務は, 直接患者に接することと, 医療用機器操作で機器に触れることが複合されてお り, 院内コンピュータマウスや医療用機器から MRSA な゙が検出されている( る. 今回の環境調查では感染対策上重要な菌の検出 は見られなかったが，患者と医療用機器を交互に触れ る医療従事者の業務内容では, 医療用撮影機器等か ら病原菌の検出が見られる可能性は十分考えられる.

CDCによる医療施設に打ける環境感染管理のため のガイドライン9)では, 患者と接触しない医療機器表 面は清拭清掃を行い，必要に応じて消毒薬を適応す るよう勧告している，また，頻繁に患者に接触する環 境表面に関しては，その他の環境表面よりも頻回に 
かつ計画的に清拭, 洗浄し消毒することと定められ ており，当院でも患者が直接触れるIP カッッテにつ いては撮影ごとにアルコール清拭するなど, 計画的な 感染管理を実施している。

HIS/RIS 端末, CR コンソールについては, 患者に 直接触れないこともあり計画的な感染管理は行われ ていなかったが, 本研究結果から 2 次, 3 次伝播先 である PC 端末, 医療機器も日常点検でアルコール清 拭や清掃を行うべきと考えられた。

救急ポータブル撮影業務において，運用可能でか つ伝播を最小限に抑えるためには，感染予防策を患 者に対する行為ごとに完結させることが重要になって くる. 具体的な撮影業務手順は, 患者に触れる前に 手指衛生を行い手袋を着用する。一連の撮影直後に 手袋を外し手指消毒，およびX 線回診機器や IP カ セッテを検査ごとにアルコール清拭を行うこととす る. 撮影室内ですべての感染予防策を講じたのち, 次の手順へ進むことを徹底させることが重要であ
る。また，不特定多数が触れる PC 端末や医療機器 も日常点検で定期的にアルコール清拭や清掃を行う ことも重要である。

以上の感染管理が病原菌の伝播を最小限に抑制で き，患者と医療従事者自身を感染から守ると考えら れた。

\section{4. 結 語}

今回，診療放射線技師の撮影業務において感染対 策にかかわる行動調査や環境調査を実施したことに より，検査室内の污染状況を認識可能となり，手指 衛生の夕イミングや環境衛生の重要性が示唆された。

\section{謝 辞}

本研究を行うにあたり環境調査・培養にてご協力い ただいた，昭和大学藤が丘病院中央臨床検査部，宇 賀神和久氏ならびに中央臨床検査部の皆様に深く感 謝致します.

\section{参考文献}

1）二本柳伸, 平田泰良, 赤星 透, 他. $X$ 線撮影による伝 播と推測した多剤耐性緑膿菌の院内感染事例. 感染症誌 2006; 80(2): 97-102.

2) 高良武博, 大湾智子, 加藤種一, 他. 看護行為前と行為 後との関連からみた手洗いと手指衛生行動。環境感染 2004; 19(2): 267-273.

3）渡部節子, 下之薗ルリ子, 大日向里美, 他. NICUに拈け るクベース収容児の MRSA 保菌率の減少——処置一手洗 い及び手袋着用の導入と感染予防行動の定着の効果一. 環境感染 2007; 22(2): 98-104.

4) 大久保憲, 小林寛伊。医療現場における手指衛生のため の CDC ガイドライン. 大阪：メディカ出版, 2003.

5）満田年宏。隔離予防策のための CDC ガイドライン一医療 環境に打ける感染性病原体の伝播予防 2007。東京：ヴァ
ンメディカル, 2007.

6) Harrison WA, Griffith CJ, Ayers T, et al. Bacterial transfer and cross-contamination potential associated with papertowel dispensing. Am J Infect Control 2003; 31(7): 387-391.

7) 外森直哉, 国島康晴, 高橋 聡, 他. 電子カルテ化に伴 う医療環境設備の変化一コンピュータ用マウスの細菌学 的検査結果一. 環境感染 2007; 22(2): 113-117.

8）中居 肇，吉田泰憲，澤田とも子．看護支援システムを含 めた医療機器が細菌伝播の温床になる可能性．環境感染 2008; 23(1): 8-12.

9）倉辻忠俊，切替照雄訳，小林寛伊監訳．医療保健施設に おける環境感染制御のための CDC ガイドライン。大阪： メディカ出版, 2004.

Fig. 1 救命救急ポータブル撮影における撮影手順

Fig. 2 救命救急ポータブル撮影時に扔ける手指衛生行動アンケート

Fig. 3 救命救急ポータブル撮影時の手指衛生行動アンケートの回答

Fig. 4 接触, 交差伝播実験における結果 蛍光色素含有塗料による手と X 線回診用機器への伝播状態.

Fig. 5 救急救命撮影準備室と環境調查による菌の培養結果

Fig. 6 環境調査で得られた菌の培養結果

Table 1 接触, 交差伝播実験における結果

Table 2 救急救命撮影準備室の環境調査結果 